Cahiers de recherches médiévales

\title{
The Political Significance of Christine de Pizan's Love Poetry
}

Tracy Adams

\section{(2) OpenEdition \\ 1 Journals}

Electronic version

URL: https://journals.openedition.org/crm/11539

DOI: 10.4000/crm. 11539

ISSN: 1955-2424

Publisher

Honoré Champion

Printed version

Date of publication: 15 June 2009

Number of pages: $353-371$

ISSN: 1272-9752

\section{Electronic reference}

Tracy Adams, "The Political Significance of Christine de Pizan's Love Poetry", Cahiers de recherches médiévales [Online], 17 | 2009, Online since 15 June 2012, connection on 15 December 2022. URL: http://journals.openedition.org/crm/11539 ; DOI: https://doi.org/10.4000/crm.11539 


\title{
RM
}

\section{The Political Significance of Christine de Pizan's Love Poetry}

\begin{abstract}
This essay argues that Christine de Pizan's love poetry represents an essential element of her political thought. In her amorous writings Christine exposes the violence that results inevitably from the ideology that obligates the nobility to defend its interests with arms. Although in her political works Christine sometimes admonishes the princes of the blood for their ambition and covetousness, only in her love lyrics does she feel free to describe the violence of her society as a systemic problem rather than the result of personal immorality.
\end{abstract}

Résumé : Les écrits amoureux de Christine de Pizan constituent une partie essentielle de sa pensée politique. Ceux-ci se caractérisent par leur critique percutante de l'idéologie qui oblige la nobilité de défendre ses intérêts avec des armes, au désavantage du roi. Dans ses écrits ouvertement politiques, Christine admoneste parfois les princes du sang de leur avarice et ambition démesurée. Pourtant, c'est seulement dans ses écrits amoureux qu'elle ose critiquer l'idéologie entière plutôt que des défauts personels.

Christine de Pizan's literary biography is generally perceived as a trajectory. The poet taught herself to write by composing light, that is, courtly love poetry: lyric cycles, love debates, and a hybrid love story combining poetry and prose. As her talents developed, she turned to weightier subjects. With her central role in the literary debate known as the querelle de la Rose (1401-1402), she established her reputation as an intellectual. From that point on, she rapidly produced a rich body of serious works reflecting the political problems of her times, including Le Chemin de longue étude (1403), Le Livre de la mutacion de fortune (1403), Le Livre des fais et bonnes meurs du sage roy Charles V (1404), Le Livre de la cité des dames (1405), Le Livre du corps de policie (1407), Le Livre des fais d'armes et de chevalerie (1410), and Le Livre de paix (1412-13). After composing some religious works later in the same decade, including the Sept Psaumes allegorisés (1410) and Les Heures de contemplation (1420), Christine laid down her pen, but re-emerged from a long silence to compose her last work, Le Dittié de Jehanne d'Arc (1429), a joyful tribute to the Maid of Orleans. As one scholar sums up the common perception of Christine's career, the poet turned «from the subject [love] to the more serious matters she wanted to study and write about. Among her more serious concerns was France. That is, she turned from lessons of self-interest for women in love to enlightened self-interest for the good of the nation as a whole. $»^{1}$

Christine's own description of her career in L'Advision Cristine (1405), where she describes her maturation as a writer, seems at first glance to justify this

\footnotetext{
${ }^{1}$ Douglas Kelly, Christine de Pizan's Changing Opinion : A Quest for Certainty in the Midst of Chaos, Cambridge, D. S. Brewer, 2007, p. 141.
}

Cahiers de Recherches Médiévales, 17, 2009 
perception $^{2}$. Nonetheless, I believe that it bears re-examination. An unfortunate effect of seeing the poet's love writings as propadeutic to her political works has been to distance the two from each other, reading the former literally, as warnings to women against seduction, and overlooking their political significance. In this essay, I propose to integrate Christine's love writings into her political corpus, suggesting that although she expressed her views on the state of kingdom in increasingly varied literary forms as her skills and knowledge grew, she must be seen as a political analyst from the very beginning. Scholars of English and, particularly, Lancastrian, court poets have treated even poetry describing youthful romantic escapades as commentary on current events. Jenni Nuttall, referring to the personal dimension of much of the poetry that followed upon the forced abdication of Richard II, notes that such «biographical strategies are themselves also responses to the changes in political rhetoric brought about by the deposition. Politicized arguments and paradigms are treated indirectly, refracted through the personal history of the poems' narrator-protagonists $»^{3}$. I believe that Christine's love poetry should be considered from a similar perspective for the following reasons ${ }^{4}$. First, literary scholarship has

\footnotetext{
${ }^{2}$ As in the well-known lines : «Adonc me pris a forgier choses jolies, a mon commencement plus legieres, et tout ainsi comme l'ouvrier qui de plus en plus en son euvre se soubtille comme plus il la frequente, ainsi tousjours estudiant diverses matieres, mon sens de plus en plus s'imbuoit de choses estranges, amendant mon stille en plus grant soubtilleté et plus haulte matieres... ». Le Livre de l'Advision Cristine, ed. Christine Reno and Liliane Dulac, Paris, Champion, 2001, p. 111, lines 45-50.

${ }^{3}$ Jenni Nuttall, The Creation of Lancastrian Kingship : Literature, Language and Politics in Late Medieval England, Cambridge, Cambridge University Press, 2007, p. 71. See also Lynn Staley, "Gower, Richard II, Henry of Derby, and the Business of Making Culture », Speculum, 75, 2000, p. 68-96.

${ }^{4}$ I do not mean to deny the validity of the approach that sees Christine's love poetry as critical of « courtly love», but to suggest another possibility. For the tradition of reading Christine's poems of love as anti-courtly love see for example Christine McWebb, «Lyrical Conventions and the Creation of Female Subjectivity in Christine de Pizan's Cent ballades d'Amant et de Dame », Christine de Pizan and Medieval French Lyric, ed. E. Jeffrey Richards, Gainesville, University Press of Florida, 1998, p. 168-183 ; Deborah Hubbard Nelson, «Christine de Pizan and Courtly Love», Fifteenth Century Studies, 17, 1990, p. 281-89; and Charity Cannon Willard, «Lover's Dialogues in Christine de Pizan's Lyric Poetry from the Cent Ballades to the Cent Ballades d'Amant et de Dame », Fifteenth-Century Studies, 4, 1981, p. 167-80 (see especially 174-75). Christine's Le Livre du duc des vrais amans has been read from a similar perspective. For Sandra Hindman and Stephen Perkinson, Christine is reworking the traditional romance to critique the genre: «Christine constructs the narrative out of verse lyrics and prose epistles that enable her to recast the standard roles played by female protagonists in the courtly romance. By inscribing herself in the work, she gives voice to the previously mute sufferings of women at the hands of a misogynistic tradition ». "Insurgent Voices. Illuminated Versions of Christine de Pizan's Le Livre du Duc des vrais amans », The City of Scholars: New Approaches to Christine de Pizan, eds. Margarete Zimmermann and Dina De Rentiis, Berlin, Walter de Gruyter, 1994, p. 221-231, especially 222-223. Roberta Krueger approaches the work from a similar perspective : "In Le Livre du Duc des Vrais Amans, the author deftly recasts romance conventions so as to reveal the dangers of courtly
} 
long read the human body as a site upon which social divisions and boundary issues are worked through ${ }^{5}$. Second, Christine herself authorizes multiple interpretations of her love writings. For example, in the opening verses of «Le Dit de la pastoure » she alerts the reader to the work's various senses, noting that what seems to be nothing but «truffe» or «fable» sometimes contains important material ${ }^{6}$. Third, Christine deploys her own autobiographical material, that is, her story of individual woe, not as an end in itself, but as a pedagogical tool, as a way of commenting on the troubles afflicting France. A final reason for integrating Christine's early poetry into her political corpus is that the poet did not abandon the theme of love despite the common perception that her amorous verse preceded her weighty works; her love poetry, in other words, should not be viewed as early light verse, but as a tried and true form of political engagement to which she returned throughout the years ${ }^{7}$.

In this essay, I will read Christine's love writings with their stories of tragic personal relationships as commentaries on contemporary political issues: as microcosmic dramatizations of the uncertainty and suffering that plagued the macrocosm of the body politic of her time ${ }^{8}$. Of course, one can argue that the personal is always political, that as stories of domination, love lyrics inevitably transmit information about contemporary power relationships. However, I believe that we can be more precise. Indeed, I will suggest that her love lyrics reveal an element of her political thought which, for reasons I will describe, she was unable to express in works dealing more overtly with government. Stated simply, in her amorous writings Christine vigorously critiques the right of the nobility to defend territory and honor with arms, a right that led to constant social unrest and greatly restricted the power of the king to defend the common good. No matter how morally upright the individual nobles may have been, a system that obliged them to call up armed defenders to settle problems inevitably promoted violence. Although in her political works Christine sometimes admonishes the princes of the blood for their

discourse for women ». Women Readers and the Ideology of Gender, Cambridge, Cambridge University Press, 1993, p. 218. For Maureen McCann Boulton «Christine's purpose in writing the Duc was different from that of her predecessors. Most of these poets, however pessimistic they might have been about their own success, reaffirmed the values of courtly love.... She used the conventions of the dit amoureux for the purposes of undermining its ideology ». The Song in the Story: Lyric Insertions in French Narrative Fiction, 1200-1400, Philadelphia, University of Pennsylvania Press, 1993, p. 241-2.

${ }^{5}$ Peggy McCracken's The Romance of Adultery : Queenship and Sexual Transgression in Old French Literature, Philadelphia, University of Pennsylvania Press, 1998, and Timothy Hampton's Literature and Nation in the Sixteenth Century: Inventing Renaissance France, Ithaca and London, Cornell University Press, 2000, offer examples of this approach. See also Stephen G. Nichols, «The Narrative of Nation. Political Allegory in $14^{\text {th }}$-Century France », Romanistisches Jahrbuch, 51, 2000, p. 153-78.

${ }^{6}$ «Le Dit de la pastoure », Euvres Poétiques de Christine de Pisan, ed. Maurice Roy, 3 vols., Librairie de Firmin Didot et Cie, Paris, 1884-96, vol. 2, p. 223-294. See p. 224, lines 24-32.

${ }^{7}$ She returned to love poetry in 1410 with the Cent Ballades d'amans et de dame. Also, her magnificent collection of ca. 1413, known today as the Queen's Manuscript, Harley 4431, contains her lyric poetry along with other works.

${ }^{8}$ L'Advision Cristine, p. 110, lines 26-27. 
ambition and covetousness, only in her love lyrics does she describe the environment of intimidation and lawlessness she observed around her as a systemic problem rather than the result of personal immorality. Specifically, Christine's amorous poetry represents a central authority - Love - as an impotent deity at the mercy of his subjects, as easily controlled by them as the mad king Charles VI was by the princes of the blood. The poet has been criticized for supporting the ideology of her various patrons in her political works. Such support is inevitable in political writings produced for a patron'. However, love poetry offered Christine a safe medium within which to wage a veiled but vigorous critique of noble ideology.

In what follows, I will read some of Christine's love writings from this perspective, focusing upon the Cent Ballades, «L'Epître au dieu d'amours », «Le Dit de la Rose », and the Le Livre du Duc des vrais amans, although the rest of her love corpus could be analyzed in a similar manner. Before considering these works and their significance, it will be useful to reconstruct the pertinent historical context, exploring how Christine and other contemporary theoreticians of peace construed the problem of noble violence.

\section{The Armagnac-Burgundian feud and contemporary peace theory}

The medieval and early modern French nobility defined themselves by their obligation to defend their honor, a concept encompassing both territory and reputation, with $\operatorname{arms}^{10}$. Frequent armed conflict was the inevitable outcome of such a social system. One particularly destructive example was the feud between the Orleanists, or Armagnacs, as the faction was known after Bernard, Count of Armagnac, assumed leadership in 1410, and the Burgundians. The feud, « arguably the most serious...in later medieval Europe, which dominated the political scene in France for over forty years », originally broke out in about 1398 with the territorial and political rivalry between the uncle and the brother of Charles VI, Philip of Burgundy and Louis of Orleans ${ }^{11}$. It assumed the shape of a vendetta with the

\footnotetext{
${ }^{9}$ Most notably by Sheila Delany in «'Mothers to Think Back Through' : Who Are They? The Ambiguous Example of Christine de Pizan», Medieval Texts and Contemporary Readers, eds. Laurie A. Finke and Martin B. Shichtman, Ithaca, Cornell University Press, 1987, p. 177-97.

${ }^{10}$ See Kristin B. Neuschel, Word of Honor : Interpreting Noble Culture in Sixteenth-Century France, Ithaca, Cornell University Press, 1989, who writes : "Power, initiative, authority, legitimacy: these things could and did spring from nobles themselves, not only from the king» (p. 18). The attitude is all the more pervasive in the early fifteenth century. See also Ellery Schalk, From Valor to Pedigree: Ideas of Nobility in France in the Sixteenth and Seventeenth Centuries, Princeton, Princeton University Press, 1986.

${ }^{11}$ Stuart Carroll, Blood and Violence in Early Modern France, Oxford, Oxford University Press, 2006, p. 9. On the Armagnac-Burgundian feud see Bertrand Schnerb, Jean sans Peur : le prince meurtrier, Paris, Payot, 2005, and Les Armagnacs et les Bourguignons. La maudite guerre, Paris, Perrin, 1988 ; Françoise Autrand, Charles VI : Folie du roi, Paris, Fayard, 1986 ; Richard Vaughan, John the Fearless : The Growth of Burgundian Power, London, Longmans, 1966 ; Michael Nordberg, Les Ducs et la royauté : Étude sur la rivalité des ducs d'Orléans et de Bourgogne 1392-1407, Studia historica upsaliensia 12, Stockholm, Svenska
} 
assassination of the latter in 1407 , which was followed by the revenge assassination of Jean sans Peur, Duke of Burgundy, in 1419, and it did not dissipate until 1435 when the Peace of Arras made allies of the Burgundians and the Armagnac Charles VII against the English.

The mechanism of feuding - and, more generally, private warfare - has been well-studied $^{12}$. Feuding appears chaotic to modern eyes. Many unrelated disputes were attached to the central quarrel between the Orleanists and the Burgundians, increasing the impression of turmoil from a modern perspective. As Timur PollackLagushenko writes of the Armagnac-Burgundian conflict: "Two of the most powerful figures [Louis of Orleans and Jeans sans Peur] in the kingdom refused to be reconciled and this animosity served as a constant around which individuals could arrange their own private interests $\gg^{13}$. Further adding to our modern impression of chaos was that shifting sides was common.

And yet, feuding was «integral to the conduct of politics in early modern France because it was one of the key forms of competition for power, a mechanism by which the struggle for dominance was played out», writes Stuart Carroll ${ }^{14}$. In

Bokförlaget,1964 ; and Léon Mirot, «L’Enlèvement du dauphin et le premier conflit entre Jean sans Peur et Louis d'Orléans (1405) », Revue des questions historiques, 95, 1914, p. 329355, and 96, 1915, p. 47-88 and 369-419. The episodic insanity of Charles VI, which limited his capability as a peacemaker between his feuding male relatives, may have exacerbated the Armagnac-Burgundian feud, on the one hand; on the other, the conflict may have been the unavoidable result of the political factionalism that characterized fifteenth-century France. Arguing the first case is R. C. Famiglietti in Royal Intrigue : Crisis at the Court of Charles VI 1392-1420, New York, AMS Press, 1986. A well-known proponent of the latter is Raymond Cazelles, La Société politique et la crise de la royauté sous Philippe de Valois, Paris: Librairie d'Argences, 1958, and Société politique, noblesse et couronne sous Jean le Bon et Charles V, Geneva, Droz, 1982.

${ }^{12}$ Guy Halsall discusses and defines feuding as opposed to the more general concept of private warfare in "Violence and Society : An Introductory Survey », Violence and Society in the Early Medieval West, ed. Guy Halsall, Woodbridge, Suffolk, UK, The Boydell Press, 1998, p. 1-45, especially 19-35. Other recent scholarship on feuding includes Stuart Carroll, Blood and Violence, and "The Peace in the Feud in Sixteenth and Seventeenth-Century France », Past and Present, 178, 2003, p. 74-115 ; Daniel Lord Smail, The Consumption of Justice : Emotions, Publicity and Legal Culture in Marseille, 1263-1423, Ithaca, Cornell University Press, 2003 ; Howard Kaminsky, «The Noble Feud in the Later Middle Ages », Past and Present, 177, 2002, p. 55-83 ; Robert Bartlett, Mortal Enmities : The Legal Aspect of Hostility in the Middle Ages, Aberystwyth: University of Wales, 1998 ; Marie-Thérèse Caron, La Noblesse dans le duché de Bourgogne, 1315-1477, Lille : Presses Universitaires de Lille, 1987 ; and Stephen D. White, «Feuding and Peace-making in the Touraine Around the Year $1100 »$, Traditio, 42, 1986, p. 195-263.

13 Timur R. Pollack-Lagushenko, «The Armagnac Faction: New Patterns of Political Violence in Late Medieval France », dissertation, Johns Hopkins University, 2004, p. 238. See also Malcolm Vale, "Seigneurial Fortifications and Private War in Later Medieval Gascony », Gentry and Lesser Nobility in Late Medieval Europe, ed. Michael Jones, New York, St. Martin's Press, 1986, p. 133-58.

${ }^{14}$ Carroll, «The Peace in the Feud», p. 7. 
other words, it was a system for settling disputes. Howard Kaminsky has shown that the French king's eventual monopolization of the right to violence has created the perception that France followed a different path from that of Germany on the way to political consolidation, but that, in fact, the difference is not as great as has long been believed. In Germany, he notes, the « governance of a king or territorial prince, like that of lesser lordships, had the primary function of preserving its subjects' property rights ; should it exceed these bounds, its armigerous noble subjects had not only the right but also the power to keep it in line. The medieval constitution of lordship, then, was manifest in feuds of noble subjects with each other and, in extreme cases, feuds of the subjects against the prince $»^{15}$. The model applies to France, as well ${ }^{16}$.

Whatever its political purpose, feuding distressed Christine and other contemporary writers. Still, they did not explicitly identify noble identity, that is, the nobles' obligation to defend themselves and their followers with arms, as the source of the violence. As Berenice Carroll has observed, during Christine's lifetime, «there was no systematic secular study of the causes and conditions of war and peace nor any substantial body of 'anti-war' literature $\gg^{17}$. This changed by the middle of the fifteenth century, when the noble right to private warfare began to be challenged by the principle that sovereign law alone could justify violence, because the damage inflicted by the Armagnac-Burgundian feud was so extensive ${ }^{18}$. However, writers of the early fifteenth-century, far from questioning the noble duty of private warfare, blamed social turbulence upon a lack of individual virtue and quarreling among the princes of the blood : upon the misuse of the duty ${ }^{19}$. Writers focused their attention upon the morally correct reasons for resorting to arms among those who enjoyed the right, drawing upon a body of theories of what constituted a just war based on Augustinian theology later refined by Aquinas, Roman law,

\footnotetext{
${ }^{15}$ Kaminsky, p. 58.

${ }^{16}$ « The key point here », Kaminsky points out, «passed over by statist historians, is that in medieval France (or indeed medieval anywhere) only a fraction of administrative, judicial and coercive authority over the people lay with a central government, what the historians call the Etat. For the overwhelming majority of people this authority was exercised by individuals or corporations holding lordship over them or otherwise possessing low, middle or high justice... » (p. 80).

${ }_{17}$ Berenice A. Carroll, «Christine de Pizan and the Origins of Peace Theory», Women Writers and the Early Modern British Political Tradition, ed. Hilda L. Smith, Cambridge, Cambridge University Press, 1998, p. 22-39, especially 29.

${ }^{18}$ Stuart Carroll, Blood and Violence. Among the aristocracy, he writes, «at least private violence was increasingly under control during the late Middle Ages; revenge killing as a feature of high politics had been eradicated by the beginning of the sixteenth century » (p. 331).

${ }^{19}$ In fact, private warfare increased again after 1559, and did not abate until the midseventeenth century. See Stuart Carroll, «The Peace in the Feud», p. 77. But important for this discussion is that Christine precedes widespread discussion of the advantages of a strong king capable of quashing noble dissension.
} 
commentaries on Gratian, the Old Testament, and chivalric codes ${ }^{20}$. But dividing those with the right to wage war from those who did not possess the right could not mitigate violence overall : « what the legal definition of right authority accomplished was chiefly to distinguish licit from illicit violence, not to restrain those possessing right authority from using it to make war on others $»^{21}$.

Like her contemporaries, Christine takes for granted the nobility's obligation to defend itself with arms. Even when she attributes the woes of France to a lack of power at the center exacerbated by strife among the princes of the blood in $L e$ Chemin de longue étude, she does not press her indictment of a social structure that encouraged powerful individuals to wreak destruction, but instead leaves the decision about how to best govern France in the hands of those responsible for the unrest in the first place ${ }^{22}$. Similar, the distressed mother figure Libera in the L'Advision Cristine appeals to her sons to stop killing each other, assuming that personal virtue alone will bring peace ${ }^{23}$. As an advisor to princes, reasoning from within noble ideology, Christine could not have done otherwise ${ }^{24}$.

True, Christine's writings on peace eloquently address the terrible effects of the feud upon the body politic - of brother eating brother - and draw increased attention to the plight of the people ${ }^{25}$. And yet, her overtly political works simply re-

\footnotetext{
${ }^{20}$ On medieval theories of peace and just war see James T. Johnson, Just War Tradition and the Restraint of War : A Moral and Historical Inquiry, Princeton, Princeton University Press, 1981, and Ideology, Reason, and the Limitation of War : Religious and Secular Concepts, 1200-1740, Princeton, Princeton University Press, 1975 ; and Frederick H. Russell, The Just War in the Middle Ages, Cambridge and New York, Cambridge University Press, 1975. Johnson has written that canonists writing on the issue «divided secular leaders into two groups, with only those above the line possessing the authority to conduct war. In general terms these latter were those with no earthly superior...»Just War, p. 151.

${ }^{21}$ Johnson, Just War, p. 152.

${ }^{22}$ Le Chemin de longue étude de Christine de Pizan, ed. and trans. Andrea Tarnowksi, Paris, Livre de Poche, 2000. See p. 462-64, lines 6329-6352, where the Sibylle sends Christine back to earth to report to the princes on the celestial debate that she has just witnessed.

${ }^{23}$ See, for example, L'Advision Cristine, p. 25, lines 1-11.

${ }^{24}$ « To commit a discourse to speak from within a given consciousness is to disarm it insofar as its critical faculty is made inoperative thereby with regard to that particular consciousness », writes Ranajit Guha, Dominance without Hegemony : History and Power in Colonial India, Cambridge, MA, Harvard University Press, 1997, p. 7. Referring to feudal society in India in words applicable equally to the European Middle Ages, Guha points out that «the voice of the historian in such a society was often indistinguishable from that of the panegyrist, the courtier and the apologist speaking for gods, kings and noblemen. The historical discourse was indeed so completely integrated here in the discourse of power that the fundamental aspects of the authority structure were never questioned even by the most questioning of writers » (p. 8).

${ }^{25}$ See Renate Blumenfeld-Kosinski, «'Enemies within/enemies without' : threats to the body politic in Christine de Pizan », Medievalia et Humanistica, 26, 1999, p. 1-15 ; and Susan J. Dudash, "Christine de Pizan and the 'Menu Peuple' », Speculum, 78, 2003, p. 788-830. See also Berenice Carroll, who explains that Christine conceived of how to maintain the peace within the body politic in an innovative way, revealing an «expanded consciousness of
} 
inscribe the roots of the problem of the violence that she laments, even as she theorizes upon just warfare, the jus ad bellum, the justifiable reasons to wage war, and the jus in bello, restraint in warfare. For example, in Le Livre des fais d'armes et de chevalerie she grants the right of the Dukes of Orleans and Burgundy to wage war upon each other, writing that « wars and battles by right must not be maintained or judged except by earthly princes who hold their lands from no one except God, as emperors, kings, dukes, and others who are called lord $\gg\left(\right.$ my emphasis) ${ }^{26}$. Key is her designation of «earthly princes who hold their lands from no one except God, as... [those] who are called lords ». This category would include important rulers along with the king, and thus, necessarily the dukes of Orleans and Burgundy ${ }^{27}$. In fact, waging war is one of the primary duties of princes, she writes in Le Livre du corps de policie (ca. 1407). Just after detailing the necessity of religious observance, Christine outlines the obligation of the prince to defend his people, couched in terms of good shepherding.

Tout ainsi et a nostre propos est du bon prince qui songneux est de la deffence et garde de son pays et peuple, pour laquelle dicte deffence et garde, lui, a qui seroit impossible estre en personne en toutes places et œuvres et charges qui y affierent, se pourvoit de tres bons aydes tant ou fait de la chevalerie comme autre part, c'est a savoir de tres vaillans chevetains qu'il congnoist et scet bons et loyaux et qui l'aiment, si comme sont connestable, mareschaulx, amiral et autres, auxquieulx il encharge que ilz soient pourveux et de tres bonnes gens d'armes bien apris et duis de guerre, lesquelz ilz tiennent liez par serment environ eulx et ne se meuvent sans leur congié, et se tiennent tout prest, a celle fin que se aucun affaire leur vient que avecques ceulx puissent saillir contre les ennemis, si que le pays ne soit mie foulez ne le peuple occis ne pillié..$^{28}$

Christine thus echoes the nobility's idealized vision of its duty to wage private war. Certainly she emphasizes in Le Livre des fais d'armes et de chevalerie that war cannot be undertaken except in certain cases by those possessing the authority to

emerging classes in society and attention to their needs and roles» (p. 31). Furthermore, continues Carroll, her writings suggest that she envisioned «a reduction of the role and authority of the church and of theological explanation», with the effect of placing responsibility for war in the hands of those waging it.

${ }^{26}$ Le Livre des fais d'armes et de chevalerie, translated as The Book of Deeds of Arms and of Chivalry, trans. Sumner Willard, ed. Charity Cannon Willard, University Park, Pennsylvania State University Press, 1999, p. 145.

${ }^{27}$ See Nordberg, p. 4-38, for an explanation of how the dukes held their lands. Berenice Carroll claims that «Christine rejected any right to private war, insisting that only the sovereign is authorized to declare war ». However, the king is not the only prince : clearly the princes of the blood figure in this category. "'On the Causes of War and the Quest for Peace' : Christine de Pizan and early Peace Theory », Au Champ des escriptures : III colloque international sur Christine de Pizan, ed. Eric Hicks, Diego Gonzalez and Philippe Simon, Paris, Champion, 2000, p. 337-58, here 350.

${ }^{28}$ Christine de Pizan, Le Livre du corps de policie, ed. Angus J. Kennedy, Paris, Champion, 1998, p. 14, lines 12-23. 
wage it, reminding her readers that « it is of primary concern to learn whether wars and battles, deeds of arms and of chivalry, of which we hope to speak are to be considered just matters or not, for in the exercise of arms many great wrongs, extortions, and grievous deeds are committed, as well as rapine, killings, forced executions, and arson; all of these may well seem to some detestable and improper $»^{29}$. And yet, « it seems manifest that wars undertaken for a just cause are permitted by God», she concludes ${ }^{30}$. Herein lies the problem. What was a «just» cause? One which she cites is «to recover lands, lordships, and other things stolen or usurped for an unjust cause by others who are under the jurisdiction of the prince, the country, or its subjects $»^{31}$. Thus virtually any disagreement - for example, the dispute between the dukes over access to royal revenues that occasioned the stand off between Louis of Orleans and Jean sans Peur in Paris of 1405 - could be justified as a cause for resorting to arms ${ }^{32}$. Although earlier in the work she praises the French for their obedience to the king, she ignores the paradox she has created in reiterating the noble right to wage private warfare : that this subjects individuals to competing loyalties.

Christine's overtly political works defend the nobility's right to wage war. And yet, if her political works must be seen as apologies for noble ideology, concealed safely within her stories of tragic love we find a sustained critique of the social structures responsible for violence and a plea for a strong central authority firmly in control of his subjects. In these «light» courtly works, we discover, to repeat Nuttall's words, «politicized arguments and paradigms» being «treated indirectly, refracted through the personal history of the poems' narratorprotagonists ».

\section{Christine's love poetry as political commentary}

Christine's love poetry depicts factional strife in condensed symbolic form. I do not mean to suggest that her amorous writings can be read as precise allegories. Even in an obviously allegorical work like L'Advision Cristine, Christine insists in her «Glose» that her characters permit diverse interpretations ${ }^{33}$. But the love poems add a poignant layer of subjective sorrow to the story of factional tensions she describes in her more overtly political works and reveal her grasp of the system that produced such tensions. To a large extent the complaints of her lyric poetry are conventional. As Daniel Poirion points out in his seminal work on courtly lyric of the fifteenth century, the genre routinely decried the rivalries and jealousies at court $^{34}$. But as Poirion demonstrates in his treatments of individual poets, each

\footnotetext{
${ }^{29}$ Book of Deeds of Arms, p. 14.

${ }^{30}$ Ibid., p. 14.

${ }^{31}$ Ibid., p. 16.

${ }^{32}$ As Frederick Russell points out, «since according to the 'inwardness' of his ethics the intention rather than the hostile act was normative, any hostile act was justified provided it was motivated by charity» (p. 17). The seminal article on the stand-off is Léon Mirot, «L'Enlèvement du dauphin ».

${ }^{33}$ For the «Glose » see L'Advision Cristine, p. 3-10.

${ }^{34}$ Daniel Poirion, Le Poète et le prince : l'évolution du lyrisme courtois de Guillaume de Machaut à Charles d'Orléans, Paris, Presses Universitaires de France, 1965.
} 
personality used conventions to produce a corpus with a distinct set of concerns. In what follows, I would like to focus upon three particularities of Christine's poetry which, taken together, create a very precise critique of a system that obliges the nobility to defend its honor with arms. The first is her representation of submission to a higher authority figure as innately positive. The second is her insistence that pain nonetheless often arises from submission because the authority figure is somehow inadequate. The third is her habit of distancing herself from love in the present while insisting that she has loved in the past. This «stranger-to-love stance » has been described by scholars discussing the poet as an opponent of courtly love ; my reading will focus upon a slightly different aspect of the position. In other love poetry of the period, « [a]u sommet de la hiérarchie des idées et des sentiments, au centre de la cour allégorique, on devine toujours la puissance du dieu régnant comme un prince : Amour... $\gg^{35}$. In Christine's love poetry, however, the God of Love is either conspicuously absent or benighted. When he is not there, his absence is signalled by the lovers' uncertainty about whether or not they have been betrayed : they never know for sure. When he is befuddled, it is the fault of deceitful individuals who appropriate his work by masquerading as lovers and confounding him to the point that he cannot distinguish the true from the false. This leaves him incapable of allotting proper rewards to his faithful followers. From her narrative position as erstwhile lover, Christine sympathizes with the horrendous uncertainty of her characters, but she is removed enough to recognize that the system, not Love, is at fault.

I will begin with the Cent Ballades, Christine's first lyric cycle, collected and published ca. 1399, in which she presents her «former lover» persona for the first time $^{36}$. This cycle, comprised of several distinct narrative strands, is structured as a lament and consolatio motivated by the distressing situation at court: jealous rivalries and the recurrent mental illness of Charles VI. But the cycle also contains two ensembles of love ballades. The first, running from 21 to 49, recounts a passionate love affair from the perspective of the woman. Her lover enters into a dialogue with her in ballades 66 to 88 . Sometimes amorous, sometimes suspicious, the female and the male characters question each other's motives, each wondering whether the other has been faithful. Their doubts are fueled by court gossips driven by jealousy and ambition to destroy others. The entwined parallel strands of political and amorous poetry gloss one another, offering different insights into the theme of power struggles at court.

In the opening ballade, Christine the narrator introduces the concepts that will sponsor Christine the poet's visions of proper comportment in politics and love

\footnotetext{
${ }^{35}$ Poirion, p. 514.

${ }^{36}$ CEuvres Poétiques, ed. Roy, vol. 1. On the structure of the cycle see James Laidlaw, «The Cent balades: The Marriage of Content and Form », Christine de Pizan and the Medieval French Lyric, ed. Richards, p. 53-82, and "L'unité des 'Cent Balades», The City of Scholars: New Approaches to Christine de Pizan, eds. Margarete Zimmermann and Dina De Rentiis, Berlin, Walter de Gruyter, 1994, p. 97-106 ; and Barbara K. Altmann, «L'Art de l'autoportrait littéraire dans les Cent Ballades de Christine de Pizan », Une femme de lettres au Moyen Âge: études autour de Christine de Pizan, eds. Liliane Dulac and Bernard Ribémont, Orléans, Paradigme, 1995, p. 327-36.
} 
throughout the cycle. These are the will («voulenté ») - which must bend to the will of those more highly placed on the social hierarchy - and genuine or «natural» emotion, which is the type of emotion that characterizes divinely ordained relationships. Love is thus both an act of will, the fulfilment of an obligation to a higher power, and a natural emotion. Love binds spouses and lovers together. It is also the emotion that binds the people and the king, as Christine will later explain in the Le Livre du corps de policie. The French are indeed lucky, she writes, because they exhibit the «plus naturel et meilleur amour et obeissance a leur prince, laquelle chose est singuliere et tres especiale vertu et grant louenge a eulx et en deservent grant merite $»^{37}$. Love presupposes humility and loyalty, which means that this genuine emotion is missing from the noble ethos, as she will lament throughout the cycle.

Let us consider more precisely how she sets up her critique. Requested to write some «beaulz diz», she concurs in this opening poem. However, she emphasizes that in so doing, she is acting to please others, "pour acomplir leur bonne voulenté », rather than to please herself. In stressing that her poetry is grounded in an act of will, Christine presents herself as an exemplum of submission, that is, as the model for proper social interaction within the body politic ${ }^{38}$. She then introduces her second major theme : her genuine emotion, her enduring love for her deceased husband. In this first ballade, then, the poet establishes one pole of the binary that will structure not only this cycle, but her love writings in general : that between the genuine emotion common to those who humbly accept their position, loving those whom they are bound to love, and the self-serving simulation of love common to those who selfishly seek to further themselves with no thought of their responsibilities.

The second poem of the Cent Ballades situates the cycle more precisely in the realm of political commentary by introducing the theme of modern moral decline caused by widespread neglect of the reciprocity upon which the healthy body politic is based. In Rome people were honored for their prowess ; in contrast, at Charles' court balance is not maintained. Whereas once the brave and intelligent, « digne d'estre de laurier couronné », received their due, too much emphasis is now placed upon «grant heritage». The poem deplores, in other words, the concentration of power in the hands of the nobility, which effectively robs the king of the power to distribute favors.

The third poem reinforces passionate love as a figure for genuine emotion with its description of the tragic drowning of Leander during one of his nightly visits to Hero. This great love, like the devotion of the cycle's narrator, will serve as a standard against which to measure the false and dangerous versions of love that the

${ }^{37}$ Le Livre du corps de policie, p. 93, lines 33-3693. On the concept of «natural » see Jacques Krynen, «Naturel : Essai sur l'argument de la nature dans la pensée politique française à la fin du moyen age », Journal des Savants, April/June, 1982, p. 169-90.

${ }^{38}$ This is not to deny the interpretation of scholars like Deborah McGrady, who reads Christine's comments on her «unwanted commission» as part of a struggle for power over the poet's text. The work functions on different levels. "Authorship and Audience in the Prologues to Christine de Pizan's Commissioned Poetry », Au Champ des escriptures, p. 2540. 
poet sees at court. The emotion is one to celebrate, even though it is inevitably touched by loss.

The fourth poem turns once again to court life, lamenting the «envie» that reigns there with its capacity for devastation. As envy led the Greeks to destroy Troy through treachery, so it will ruin the French kingdom. Set against the backdrop of the rivalry between the dukes of Orleans and Burgundy, Christine's emphasis upon the dangers of envy, rumor, and treachery gains its historical relevance. Peace accords between the quarrelling dukes of Orleans and Burgundy blame their conflict upon envy and rumors. One accord, restoring peace after a near clash of arms, attributes the problem to "aucuns rapors fais à ceulx comme l'en dit, par aucunes personnes, tant ès temps passez comme nagueres $»^{39}$. The noxious influence of envy and rumor as detailed in Christine's love poetry can be located squarely in the context of the conflict between the dukes.

In this context, I would suggest, the cycle's sets of love poems serve as the emotional substratum or microcosmic versions of Christine's socio-political analysis. For Christine, relationships, including love relationships, are hierarchical and carry reciprocal obligations. It is a foregone conclusion that the lady will yield : Love is her superior, and she is therefore obligated to submit. Yielding to Love is a positive act of submission to a higher authority. And yet, the act brings pain. The cause of the pain is central to Christine's vision of love. The lady is not unhappy because she is betrayed by a deceitful lover : neither readers of Christine's love works nor the victims of love in the works possess sufficient information to judge whether abandonment has taken place or not. The lady is tormented, rather, by her inability to ascertain whether her love is fully reciprocated. And this results from an absence at the center of the system of rewards. Although Love demands submission, it or he (the figure is sometimes personified) is fatally incapable of giving lovers the assurances they deserve. The distress of the lovers of the Cent Ballades reflects that of the good people of the realm, obediently loving their ruler, Charles VI. But the French king, like Love, is unable - not unwilling - to appease his people's anguish. The reason is that he is deceived by disloyal, duplicitous courtiers, who upset hierarchies for their own gain. Christine's $95^{\text {th }}$ poem laments the madness of Charles VI, reading his malady as the result of «noz pechiez $»^{40}$. Charles himself is not to blame for the chaos into which the kingdom has fallen : it is his people who are at fault. But who exactly does Christine indicate with this «noz»? The poems surrounding the Charles poem, 93-97, suggest an answer, for they exhort the powerful to be less covetous of worldly goods and to maintain loyalty. Loyal only to themselves and seeking advancement at the expense of the truly deserving, the nobility are shown in these poems to possess a corrupt ethos responsible for the kingdom's distress.

Here Christine chastises noble ideology - not just individual immorality - in a way she fails to do in her political works. She questions the very identity that equates honor with acquisition and force. Charles, the pin around which the

\footnotetext{
${ }^{39}$ Louis Douët-d'Arcq, Choix de pièces inédites relatives au règne de Charles VI, 2 vols., Paris, Renouard, 1863, vol. 1, p. 221.

${ }^{40}$ On the sins of the French as an explanation of Charles' malady, see Bernard Guenée, La Folie de Charles VI, Paris, Perrin, 2004, especially p. 147-51 and 190.
} 
kingdom is meant to turn, has been irreparably harmed by the crimes of the nobility who take advantage of his illness to further their own interests. In other words, Christine expresses in the register of courtly love her disapproval of ambition for personal glory that refuses to submit itself to a higher authority; her disoriented Amour is a metaphor, I would suggest, for the king manipulated by the princes of the blood.

The «Epître au dieu d'amours» of 1399 depicts a social economy in a similar state of dysfunction. Particularly interesting, however, is the fact that Christine lends the God of Love, Cupid, (and, I would suggest, Charles VI) a voice, letting him explain why his court has become so divided. The problem is that fraudulent lovers mimic love so accurately that Cupid himself cannot tell the false from the loyal. He therefore cannot reward the deserving and banish the dangerous! Cupid's outcry «Mais se bien vient a ces faulx d'aventure,/ N'est pas droit bien, combien je l'endure » might just as well have been emitted by Charles ${ }^{41}$. Both are impotent before the princes. During his lucid moments Charles was torn from both sides by his uncle and his brother. In condemning the practice of feigning love so skillfully that authentic and false lovers become indistinguishable, Christine laments the constant jockeying to promote oneself over one's opponents with the attendant hypocrisy and médisance that threatened to degenerate into all-out war on a political level.

Like the Cent Ballades, this poem recognizes the danger posed by envious médiseurs, slanderers at court. Cupid demands that his followers treat women with respect. Moreover, he implicitly encourages the court to support the authority of Queen Isabeau of Bavaria, making an impassioned plea for the queen as mediator by reminding readers of the Virgin Mary's exalted position next to God (p. 62, lines 572-590). Since at least 1401, Isabeau had been mediating between the unruly dukes when the king was mad. During Philip's six-month absence from the kingdom in 1401, Louis took advantage of the situation to have a number of his men appointed to important government positions. A stand-off ensued upon Philip's return, but bloodshed was avoided through negotiations in which Isabeau was intimately involved. The document laying out the terms to which the parties finally agreed notes that Isabeau conducted « une grant meure déliberation avec les Princes $»^{42}$. The negotiations were crowned with a ritualistic dinner. In March, 1402, Isabeau was appointed by Charles VI to serve as official mediator between the battling dukes. In July of the same year, the king augmented her authority with an ordinance that reauthorized her to mediate between his unruly relatives and furthermore authorized her to preside over the royal Council during his periods of debility ${ }^{43}$. Cupid highlights women's gentleness, a promotion of Isabeau at the expense of the warlike

${ }^{41}$ Thelma Fenster and Mary C. Erler, ed. and trans., Poems of Cupid, God of Love : Christine de Pizan's Epistre au Dieu d'amours and Dit de la Rose, Thomas Hoccleve's Letter of Cupid. With George Sewell's The Proclamation of Cupid, Leiden, Brill, 1990, p. 38, lines 87-88.

${ }^{42}$ Douët-d'Arcq, vol. 1, p. 220-226. See also the Chronique du Religieux de Saint-Denys contenant le règne de Charles VI, de 1380-1422, ed. and trans. Louis Bellaguet, 6 vols., Paris, Crapelet, 1839-52 ; reprinted Éditions du Comité des travaux historiques et scientifiques, 1994, vol. 3, p. 116-18.

${ }^{43}$ Douët-d'Arcq, vol. 1, p. 240-43. 
dukes. Unlike men, women are not inclined «a ce, n'a user de batailles,/ N'a gent tuer, në a faire fouailles / Pour bouter feu...» (p. 66, lines 659-61). Cupid brings his speech to a close by decreeing that anyone who uses "faulx desloyaux semblans » to deceive women will be banished from the kingdom (p. 70, line 774).

Within one or two years of penning this work, Christine dedicated the collected letters of the Querelle de la Rose, which contained her own vigorous defense of feminine character against the misogynistic discourse promulgated in the Roman de la Rose, to the queen, asking her to mediate in the quarrel. The reasons for defending women against misogyny appear so self-evident to modern readers that we rarely pause to ponder why Christine did so ; also, Isabeau's unjustified negative reputation has created an impression among many of Christine's modern readers that the poet regarded the queen as morally deficient ${ }^{44}$. But the political situation at the moment that Christine wrote suggests that her promotion of feminine virtue against male slander responded to a specific problem. Isabeau was the representative of royal authority: the attempts of the dukes to control the royal Council constitute usurpation.

An absent and impotent God of Love marks «Le Dit de la rose» of 1401. He does not appear himself, but rather sends his messenger, the goddess Loyalty, to speak at a Valentine's Day gathering to invite the Duke of Orleans and his dinner guests. The purpose of the speech is to convince the group to form the Order of the Rose. This order will be dedicated to honoring women and containing gossip. Everyone present accepts the invitation, and, pleased, Loyalty flies back to Love to tell him the good news.

The sleeping narrator is awakened later in the night, after she has already witnessed the appearance of Loyalty, by a glowing light and a voice that reminds her that physical strength is merely vulgar if not accompanied by inner goodness, «bontez qui viennent de l'ame» (p. 10, line 359). The voice explains that Love is greatly saddened by the rampant slander perpetrated against both women and men. Slander, médire, is «tel glaive et si faite darde / Que meismes cil qui le balance/ Occist et cil sur qui le lance» (p. 112, lines 418-20). To halt the acid-dripping tongues, Love has sent Loyalty to create a new order. But if Love is distressed by the turmoil he observes, he can only request that his followers desist voluntarily; he can not force them to heel.

\footnotetext{
${ }^{44}$ Isabeau's vilification is now common knowledge. See Heidrun Kimm, Isabeau de Baviere, reine de France 1370-1435. Beitrag zur Geschichte einer bayerischen Herzogstochter und des französischen Königshauses (Munich: Stadtarchiv, 1969); Yann Grandeau, «Le Dauphin Jean, duc de Touraine, fils de Charles VI, 1398-1417», Bulletin philologique et historique, 93, Comité des travaux historiques 2, Tours, 1971, p. 665-728; Theodor Straub, "Isabeau de Bavière, Legende und Wirklichkeit», Zeitschrift für Bayerische Landesgeschichte, 44, 1981, p. 131-155 ; Rachel C. Gibbons, "The Active Queenship of Isabeau of Bavaria, 1392-1417 », dissertation, University of Reading, 1997, and «Isabeau of Bavaria, Queen of France (1385-1422): The Creation of an Historical Villainess », Transactions of the Royal Historical Society, series 6.6, 1996, p. 51-73 ; Marie-Véronique Clin, Isabeau de Bavière : la reine calomniée, Paris, Perrin, 1999 ; Philippe Delorme, Isabeau de Bavière: épouse de Charles V, Mère de Charles VII, Paris, Pygmalion, 2003.
} 
In light of the political relevance of these earlier love poems, it seems reasonable to examine the Livre du Duc des vrais amans (1405), a hybrid work of poetry and prose that recounts the story of a passionate love affair, from a similar perspective. The years 1403-1407 were highly productive for Christine, and 1405 was particularly fraught by a dispute that led Louis of Orleans and Jean of Burgundy, Philip of Burgundy having died in 1404, to summon their armies, creating terrible anxiety among the Parisians. Throughout September and the first weeks of October, 1405, they watched nervously while the dukes amassed troops and published defamatory letters about each other to justify their causes. The situation was finally defused when a set of mediators led by the queen convinced the two to come to terms. Le Livre du Duc des vrais amans, like Christine's other love poetry, is an appeal against slander and factionalism, and, in this context, I suggest, an indictment of a system that encouraged private warfare rather than submission to the king's higher authority.

The story begins, like the Cent Ballades, with the narrator explaining that although she is not particularly interested in writing a love story, she has agreed to do so because she has been summoned by a lord whom she must obey ${ }^{45}$. The story, then, like the Cent Ballades, is predicated upon an act of obedience, and it further emphasizes the importance of obedience in its depictions of the lovers' ceding to the demands of Love. The duke, who represents Louis, I suggest, actively seeks to submit himself to Love (p. 69, lines 71-74), a positive inclination of the will that produces natural love : that highly valuable emotion, that social glue. Once in love, he accepts the superiority of the lady (she is both older and more highly ranked than he) who represents Isabeau, saying to her: "suis de corps et d'ame / Tout vostre, tres chere dame...» (p. 155, lines 2701-02). For a time the lovers lead an idyllic existence, adhering to social hierarchies; they are above reproach. And yet, their relationship is turned against them. Gossip about their affair destroys the lady.

To blame are the médisant of the court. The story exposes their operation in a letter of warning to the lady from her duenna, Sebille, who advises the lady to shun love, explaining that even if she resists seduction, she will be ruined. This is because the appearance of adultery is just as damaging as the fact. In a world where women are relentlessly scrutinized, to fall in love is disastrous, for the emotion creates visible physical changes upon its victims, and, as soon as gossips notice the symptoms of love, they spread the news. Sebille begins her letter by observing that news of the lady's unbecoming behavior has reached her, a claim she bases on a report that the lady appears to be happier than in the past (p. 173, lines 60-70). Regardless of the truth, any lady who gives the appearance, not even of being fond of a young man, but of being happy, will not only be judged to be in love, but will be assumed to be involved in an illicit affair.

The power of gossip to destroy is thus very real, and it does not matter whether or not it is accurate. Christine emphasizes this by leaving open the question of whether or not the duke and the lady sleep together. She describes the lady's efforts to circumscribe her own desire and to keep the duke's under control. When the lady writes to the duke that she agrees to be his «amie», she stipulates the

\footnotetext{
${ }^{45}$ Le Livre du Duc des vrais amans, ed. Thelma S. Fenster, Binghamton, NY, Medieval and Renaissance Texts and Studies, 1995, p. 67-68.
} 
conditions to which he must adhere : he must guard her honor or good reputation and never so much as ask her to do anything against her will (p. 142, lines 11-17). The duke responds enthusiastically. The lady plans a meeting, instructing the duke to disguise himself as a varlet. When they are alone at last, the duke is so overcome with emotion that he cannot speak, but leaves everything to her - including the decision of whether their relationship will be consummated that evening. Once again, the lady asserts her control over the situation and her own desire. But we are not told if the relationship is consummated. As Christine's withholding of information makes clear, the fact is not what matters. Noxious gossip does not seek verification.

The lady is eventually undone by poisonous tongues. This story, which has generally been read as an indictment of courtly love relationships, can fruitfully be considered an allegory of court politics, a version of the Armagnac-Burgundian feud that offers an account of the alliance of Louis of Orleans and Isabeau of Bavaria after the death of Philip of Burgundy. The court, including the king's officers and his royal Council, was divided into factions loyal to the Duke of Orleans and Jean sans Peur, new Duke of Burgundy. Isabeau was allied as her family obligations demanded with her husband's brother, Louis of Orleans, whose standing as son of one king and brother of the current king far surpassed that of Jean sans Peur, a mere cousin of the king.

However, she fell victim to the propaganda machine of the disgruntled Jean sans Peur ${ }^{46}$. Jean's attacks upon Louis of Orleans and the queen took place during the years of 1404 and 1405 . Furious at being checked by the pair, a cohort of Burgundians, acting on their leader's behalf, criticized them for mismanaging the kingdom. As we have noted, médisance is a convention of love poetry. However, once again, it can be historically contextualized. The gossip circulated by the Burgundians is treated as a serious problem in contemporary sources. The Orleanistinclined chronicle attributed to Cousinot claims that the Duke of Burgundy, seeking to turn the people against Louis and Isabeau, spread lies «par tavernes $»^{47}$. Other

\footnotetext{
${ }^{46}$ On this family alliance see R. C. Famiglietti, Royal Intrigue. After the death of Philip of Burgundy, Isabeau allied herself with Louis. She also signed an alliance with Jean sans Peur shortly after the death of his father. However, the alliance with Jean laid out very specific limitations : she would be his ally only when she was not previously obligated by closer familial ties. Famiglietti explains that «she would use all her power against everyone except the king, her children, and all those to whom by 'reason and honesty' she was more obliged because they were more closely related to her than John was. In other words, she would be unable to help John against the duke of Orléans, since, as her brother-in-law, he was more closely related to her, and she would be unable to help him against such personages as the king's uncles, the dukes of Berry and Bourbon » (p. 40).

${ }^{47}$ See the Chronique de la Pucelle ou chronique de Cousinot, suivie de la chronique Normande de P. Cochon, relatives aux règnes de Charles VI et de Charles VII, restituées à leurs auteurs et publiées pour la première fois intégralement à partir de l'an 1403, d'après les manuscrits, avec notices, notes, et développements, ed. Auguste Vallet de Viriville, Paris, Adolphe Delahays, 1859 ; reprinted Elibron Classics, 2002, p. 109. Further on the Burgundian propaganda machine see Michael Nordberg, «Les Sources Bourguignonnes des accusations portées contre la mémoire de Louis d'Orléans », Annales de Bourgogne 31, 1959, p. 81-98,
} 
incidences are recorded in the chronicle of the Burgundian-leaning Michel Pintoin, known as the "Religieux of St. Denis », who mentions that during the stand-off between the Dukes of Orleans and Burgundy of 1405, gossip flew back and forth between the factions at court : one could not say anything without the other being informed about it by false courtiers, whose hateful words only augmented the animosity between the two ${ }^{48}$. A Burgundian pamphlet called the «Songe véritable» presents the character Fortune vowing to ruin the queen's reputation within the year ${ }^{49}$. It should be noted that given Isabeau's proximity to power and the medieval propensity to cast women as lightning rods for social problems, the fact that only Jean sans Peur and his immediate faction criticized her bespeaks the high regard in which she was held rather than the contrary. Christine, with her close ties to the House of Burgundy (Philip commissioned her to compose Le Livre des faits et bonne moeurs du sage roi Charles $V$ in 1404) and the House of Orleans, would have been sensitive to the Burgundian hostility towards Isabeau as long as the queen was associated with their arch-enemy, Louis.

The drift into despair of the lady of Le Livre du Duc des vrais amans reflects Isabeau's treatment at the hands of Jean sans Peur. Other of Christine's love writings could be analyzed from a similar perspective. For example, the Cent Ballades d'amans et de dame (ca. 1410) reproduces the same complaints of the Cent Ballades, featuring a Love who cannot guarantee the rewards of his lovers. The danger is demonstrated all the more forcefully in this story, for the lovelorn dame seems to die at the end ${ }^{50}$. Produced during a period when Jean sans Peur had seized control of the government and the Armagnacs had allied themselves in the League of Gien, the narrative reflects the sorrow of a realm whose center, the king, was absent.

\section{Conclusion}

The conflict between the Orleanists and the Burgundians has sometimes been regarded as one between two ideologies of kingship. Louis of Orleans and his faction have been said to represent a movement towards centralization while the Burgundians with their formidably powerful apanage remain resolutely anchored in

and Charity Cannon Willard, «The Manuscripts of Jean Petit's Justification: Some Burgundian Propaganda Methods of the Early Fifteenth Century », Studi Francesi, 13, 1969, p. 271-280.

${ }^{48}$ The Chronique du Religieux de Saint-Denys, vol. 3, p. 330.

${ }^{49}$ The «Songe véritable» has been edited by Henri Moranvillé, Mémoires de la Société de l'Histoire de Paris et de l'île de France, 17, 1890, p. 217-438. The pertinent reference is : «Je ly feray avoir tel honte,/ Et tel dommage et telle perte, / Qu'en la fin en sera deserte » (p. 276, lines 1736-38). In other words, Fortune has not yet turned her wheel, or, at least, she has not yet given it a full spin.

${ }^{50}$ See Christine de Pizan: Cent ballades d'amant et de dame, ed. Jacqueline Cerquiglini, Paris : Union Générale d'Editions, 1982. In poem IX, p. 40, the male lover supplicates Amour to grant him the love of the lady he desires. In poem X, p. 41, Love, believing in the man's sincerity, grants him his wish. But as the action unrolls, the actual motivations of the man become unclear; at least the lady believes him to be insincere and dies of sorrow. We find once again the structure of a well-intentioned but befuddled Amour. 
a system of the king as first among peers ${ }^{51}$. Whether or not the schema is valid in fact (as I have noted here, recent scholarship on feuding indicates that the French road to absolutism was anything but direct) is less important for the purposes of this essay than Christine's perception that the immense power of rival lords and the corresponding weakness of the king represented a threat to the kingdom. Her exhortations to the people to obey the king and not rebel (as Jean sans Peur regularly urged them to do) in the third book of Le Livre du corps de policie, for example, reveal how deeply she feared that duke's power to manipulate the Parisians. But whereas her belief that a strong king and subdued nobility were necessary for stability is absent from her political works where she reiterates the noble obligation to defend its honor, it is forcefully present in her love writings.

I have argued that Christine's love poetry gains new dimensions when considered in the context of its unique political situation. Furthermore, imagining Charles VI's court in its physical reality adds urgency to her descriptions of court strife. The king's bureaucracy depended upon the service of the princes of the blood and the nobles, which he was required to purchase with offices and pensions. Thus, he was constantly solicited. Crowds seeking favors would have swarmed about him whenever he appeared. In his private chambers, he would have been subject to the constant entreaties of his male relations, who would have tried to take advantage of his fragile mental health. As Werner Paravicini remarks, even if the king was the source of all legality, he was helpless before the requests of his courtiers. Indeed, the king was «pratiquement désarmé face à l'insistance qui vient de l'intérieur », as Paravicini describes $\mathrm{it}^{52}$. Christine would have understood the process of solicitation all too well ; her father, Thomas de Pizan, a member of Charles V's inner circle as his physician/astrologer, lost his position when that king died, and he was forced to join the line of those seeking favors from the new king. Life was never the same for Thomas or his family; the death of Charles V was the first in the series of disasters that led Christine eventually to write to make a living. She herself sought patronage for her writing career from the various members of the royal family.

From this position, she would have been acutely conscience of the activity of the factions at court, once the madness of the king set in and the dukes of Orleans and Burgundy began vying for power. Christine would have experienced these leaders as aggressively pursuing advantage at the expense of the king, and the lesser members of the court as seeking and sometimes receiving awards they did not necessarily deserve. Most of all, she would have been aware of the increasing menace of violence, and she would have lived through the most serious early threats in her residence in Paris, located near the king's principal residence at the Hôtel

\footnotetext{
${ }^{51}$ On the subject see Autrand, p. 204-213, and Schnerb, Les Armagnacs et les Bourguignons, p. 49-57, both of whom emphasize the attempts of the Marmousets and Louis of Orleans to increase centralization of the government.

52 Werner Paravicini, «Administrateurs professionnels et princes dilettantes», Histoire comparée de l'administration $I V^{e}-X V I I I^{e}$ siècles : actes du XIV $V^{e}$ colloque historique francoallemand, Tours, 27 mars- $1^{e r}$ avril 1977, ed. Werner Paravicini and Karl Ferdinand Werner, Munich, Artemis Verlag, 1980, p. 174.
} 
Saint-Pol, on the eastern side of Paris on the right bank of the Seine, if she continued to inhabit the house in which her father had installed his family ${ }^{53}$.

« The history of dissent in the Middle Ages is also a history of (frequently expanding or shifting) 'textual communities' and inevitably of the language practiced within them », writes Lynn Staley ${ }^{54}$. While carving out a niche for herself as a court poet, Christine could have incorporated the tensions she felt into her lyric poetry without fear of disapprobation from her own textual community ; but later, when well established and writing upon «weighty » subjects, she would have written from the perspective of her patrons, whom it was possible to correct only indirectly, without throwing into question the very foundations of their social privileges. The integration of the love writings into Christine's corpus as political commentary does not deny their interest as courtly love lyrics. Rather, it broadens their interest, recognizing that stories of love are inevitably stories of power. The approach offers insight into the social purposes of the late fourteenth and early fifteenth-century love lyric. During one of the most troubled periods of French history, writing about the tribulations of love was a means of discreetly forwarding a serious political commentary on the necessity of a strong king.

Tracy Adams

University of Auckland

${ }^{53}$ See Simone Roux, Christine de Pizan : Femme de tête, dame de cœur, Paris, Payot, 2006, p. 43-44.

${ }^{54}$ Staley, « Gower, Richard II, Henry of Derby », p. 69. 